\title{
CONTAMINATION WITH HEAVY METALS AND PAH'S IN SOIL IN THE CANTON SARAJEVO IN PERIOD 2009-2015
}

\author{
Nura REŠIDOVIĆ ${ }^{1 *}$, Helena FILIPOVIĆ ${ }^{1}$, Alema MRKOVIĆ ${ }^{1}$, Amra SEMIĆ ${ }^{1}$, \\ Ahmedin SALČINOVIĆ ${ }^{1}$
}

UDK 631.453(497.6)

\begin{abstract}
In accordance with the role and importance of which in the world and in our country is attached to soil as a bio production factor, the need to examine and protect soil from contamination is imposed. Heavy metals are very common contaminants of soils. Highly toxic and carcinogenic PAHs are natural components of raw petro chemical compounds. Due to their negative influence on plants and animal world as well as on human population, it is necessary to evaluate and determine heavy metals and PAHs content in soils, especially in ones intended for agricultural production.

In this work, we have examined agricultural and urban soils in the Canton Sarajevo, for content of heavy metals and polycyclic aromatic hydrocarbons. Analyzed samples were in scattered state, taken from a depth of 0-30 $\mathrm{cm}$. The total number of determined soil samples was one hundred and twenty (120), in the period of 2009-2015.

According to determined general chemical characteristics, soils are from slightly acetous to slightly alkaline. According to mechanical texture composition, examined soils have showed the following texture marks by Ehwald: clay and sandy loam.

Using flame/electrothermal atomic absorption spectrometry and gas chromatography with FID detection we have established the content of seven heavy metals and polycyclic aromatic hydrocarbons. In determining the content of heavy metals following methods were used: BAS ISO 11466:2000 and BAS ISO 11047:2000, and for PAHs the method was BAS ISO 18287:2008. Results were compared with the limit values from "Regulation on determining the allowable amounts of harmful and dangerous substances in soils and methods of their examination" specified in Official Gazette of the Federation of B\&H, No. 72/09.
\end{abstract}

Keywords: contamination, heavy metals, PAHs, AAS method, GC-FID

\footnotetext{
${ }^{1}$ Federal Institute of Agropedology, Dolina 6, 71000 Sarajevo, Bosnia and Herzegovina

*Corresponding author: Nura.Rešidović@fzap.gov.ba
} 


\section{INTRODUCTION}

It is a well-known fact that the land is a natural wealth, but unlike other resources such as mineral resources, forests, flora and fauna, his reserves, along with reserves of water and air, were considered to be inexhaustible. However, with the increase in urbanization, we have witnessed a disturbing degree of threat and soil contamination in all spheres of the environment. So, the land did not receive any necessary attention, although symposiums of pedologists have warned the public about the land care, as one of the most important parts of the ecosystem (plant - animal - man - water - air). A modern system of land management as a multifunctional medium, underlines that, in addition to the primary production of biomass, it has a set of other functions/roles, that are the foundation of establishing a balanced system and sustainability. All soil functions are inherent and equally important, and they include: ecological-regulation functions of the soil (receiver, collector and exchanger of various defects), such as: climate-regulation, spatial function, carrier of infrastructure, water purifier, source of genetic resources and biodiversity, landscape design, and the role of soil as a historical media-the development of civilization.

\section{MATERIAL AND METHODS}

Our research included the field and laboratory examination and data processing. Researches were carried out in 2009, 2010, 2012, 2013, 2014/15 year. 120 soil samples, from a depth of $0-30$ $\mathrm{cm}$, were taken from agricultural and urban land. The main task of the research was to determine the level of contamination of agricultural and urban land with inorganic pollutants: lead $(\mathrm{Pb})$, cadmium $(\mathrm{Cd})$, zinc $(\mathrm{Zn})$, nickel $(\mathrm{Ni})$, chromium (Cr), cobalt (Co) and copper $(\mathrm{Cu})$, and with (PAHs) polycyclic aromatic hydrocarbons as organic pollutants. The limit values were determined in accordance with the Regulation on determining the allowable amounts of harmful and dangerous substances in soils and methods of their examination (Official Gazette of the Federation of B\&H, No. 72/09).

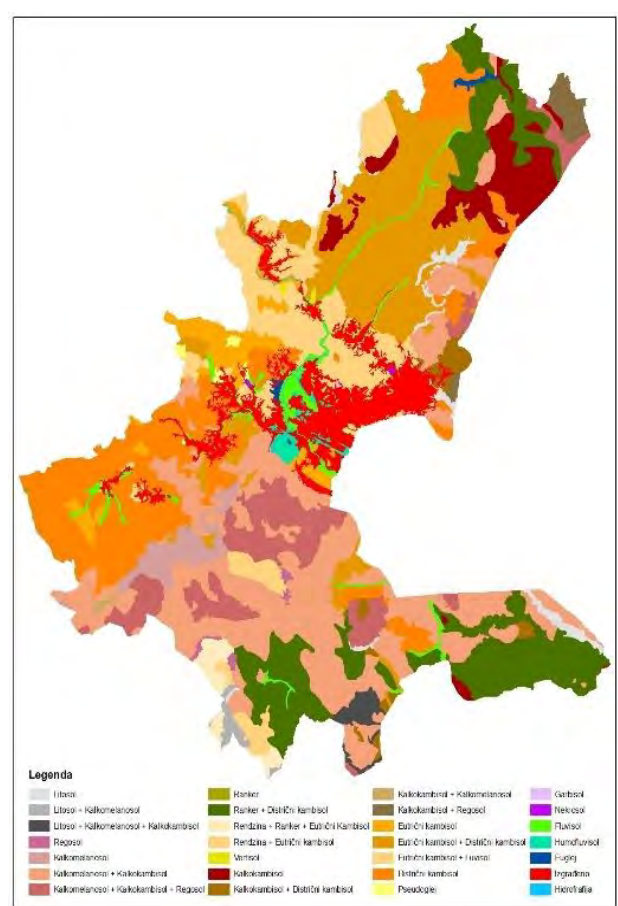

Figure 1. Pedological map of Canton Sarajevo Source: Čustović et al., 2011 
Sarajevo Canton occupies area of 126,994.59 ha, of which agricultural land is $48,118.97$ ha, forest is $10,287.38$ ha and unfertile land is $10,287.38$ ha. The most represented with $90 \%$ are the automorphic soils (lithosols, regosols, rendzinas, rankers, mould, calcocambisols, distric cambisols and eutric cambisols). Hydromorphic soils are represented with $10 \%$ (fluvisol, pseudogley, semigley and eugley) A study of the use value of the land of the Canton Sarajevo are presented in Figure 1. The climate is continental, semi-humid with an annual average temperature of $9,5^{\circ} \mathrm{C}$, and annual average precipitation of $961 \mathrm{~mm}$ (according to Lange's rain factor).

\section{RESULTS}

Some agricultural and urban soils in the Canton Sarajevo were examined for the content of heavy metals and PAHs. 120 soil samples, taken from a depth of 0-30 cm, were analysed in scattered state. We have shown the average values of the results of the heavy metals content in the soil, analysed by atomic absorption spectrometry (flame/graphite furnace), and the results of the PAHs determination, analyzed by gas chromatography with FID detection. BAS ISO11466:2000 and BAS ISO11047:2000 were used for heavy metals while BAS and ISO18287:2008 for the PAHs determination Values of the results are presented in Tables 1-7 and Graphs 1-5.

Table 1. The textural composition of the soil

\begin{tabular}{cccccc}
\hline Year & \multicolumn{3}{c}{ The percentage content of soil particles with } \\
& $\begin{array}{c}\text { Rough sand } \\
\text { diameter in } \mathbf{~ m m ~}\end{array}$ & $\begin{array}{c}\text { Fine sand } \\
\mathbf{2 - 0 . 2}\end{array}$ & $\begin{array}{c}\text { Fine Silt } \\
\mathbf{0 . 0 . 0 2}\end{array}$ & $\begin{array}{c}\text { Clay } \\
\mathbf{0 . 0 2}-\mathbf{0 . 0 0 2}\end{array}$ & $\begin{array}{c}\text { Texture mark by } \\
\text { Ehwald }\end{array}$ \\
\hline \hline $\mathbf{0 0 0 9}$ & 0.38 & 62.30 & 23.89 & 13.42 & Sandy loam \\
\hline $\mathbf{2 0 1 3}$ & 13.21 & 59.82 & 10.69 & 9.22 & Loamy sand soil \\
\hline $\mathbf{2 0 1 4} / \mathbf{1 5}$ & 8.20 & 65.71 & 13.19 & 12.70 & Loamy sand soil \\
\hline
\end{tabular}

According to the above test results, textural composition of the soil shows no major differences per year, and Loamy sand soil mainly prevails. 
Table 2. General chemical properties of the soil

\begin{tabular}{cccccc}
\hline \multirow{2}{*}{ Year } & Type of soil & \multicolumn{2}{c}{ pH values in } & $\begin{array}{c}\text { Humus } \\
\text { content }\end{array}$ & $\begin{array}{c}\mathbf{C a C O}_{3} \\
\text { content }\end{array}$ \\
\cline { 3 - 6 } & & $\mathbf{H}_{2} \mathbf{O}$ & KCl & in \% & in \% \\
\hline $\mathbf{2 0 0 9}$ & Agricultural and urban & 6.62 & 5.66 & 3.27 & 0.93 \\
\hline $\mathbf{2 0 1 0}$ & Agricultural and urban & 6.40 & 5.60 & 2.90 & 0.45 \\
\hline $\mathbf{2 0 1 2}$ & Agricultural and urban & 6.97 & 5.75 & 2.78 & 0.82 \\
\hline $\mathbf{2 0 1 3}$ & Agricultural and urban & 6.80 & 5.67 & 3.21 & 0.57 \\
\hline $\mathbf{2 0 1 4 / 1 5}$ & Agricultural and urban & 8.45 & 6.87 & 2.35 & 0.98 \\
\hline
\end{tabular}

The $\mathrm{pH}$ value in $\mathrm{H}_{2} \mathrm{O}$ is in the range from 6.40 to 8.45 , while in $1 \mathrm{MKCl}$ ranges from 5.60 to 6.87 . According to Schefter-Schatschabela limit values, soil is mildly acidic to mildly alkaline. The humus content ranges from $2.27 \%$ to $3.21 \%$, and according to Gračanin the soil has low to medium humus content. The content of calcium carbonate is from $0.45 \%$ to $0.98 \%$ and it is a poorly calcareous soil.

Table 3. Average results (in $\mathrm{mg} / \mathrm{kg}$ ) of heavy metals and PAHs in 2009

\begin{tabular}{llcccccccc}
\hline year & Soil type & Pb & $\mathbf{Z n}$ & $\mathbf{C d}$ & $\mathbf{C u}$ & $\mathbf{N i}$ & $\mathbf{C r}$ & $\mathbf{C o}$ & $\mathbf{P A H}$ \\
\hline \hline \multirow{2}{2009}{} & agricultural & 62.18 & 118.9 & 1.94 & 101.5 & 134.2 & 82.88 & 22.88 & n.d. \\
\cline { 2 - 9 } & $\begin{array}{l}\text { urban } \\
\text { Limit } \\
\text { values }\end{array}$ & 68.36 & 164.3 & 2.22 & 55.35 & 60.04 & 33.10 & 13.88 & n.d. \\
\hline
\end{tabular}

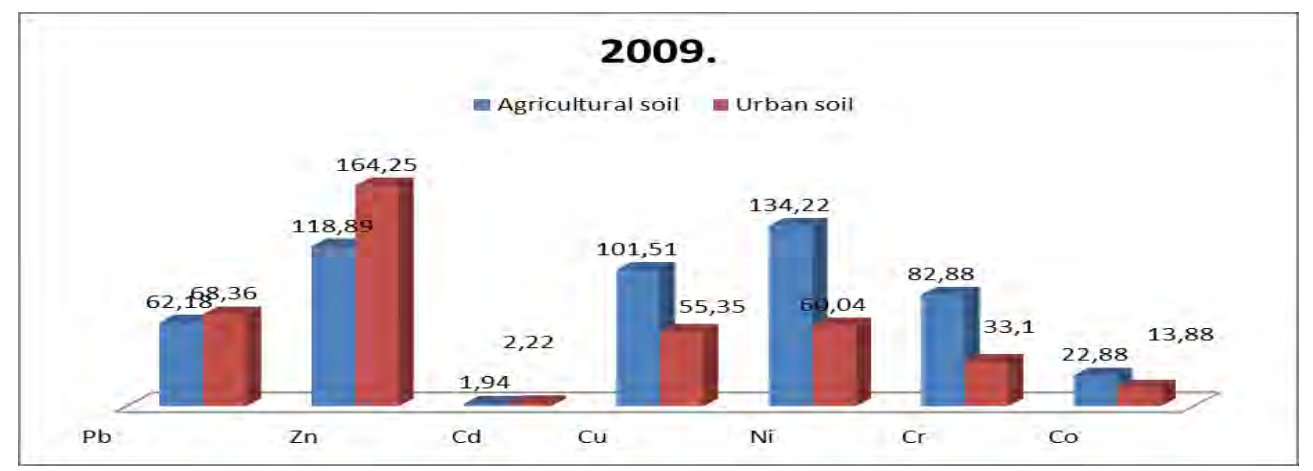

Graph 1. Average results of heavy metals for 2009 
- Cadmium content is above the limit value, ranging from $1.94 \mathrm{mg} / \mathrm{kg}$ on agricultural soils, and $2.22 \mathrm{mg} / \mathrm{kg}$ in urban soils.

- Copper content is above the limit value, ranging from $101.51 \mathrm{mg} / \mathrm{kg}$ on agricultural soils, and $55.35 \mathrm{mg} / \mathrm{kg}$ in urban soils.

- Nickel content is above the limit value, ranging from $134.22 \mathrm{mg} / \mathrm{kg}$ on agricultural soils, and $60.04 \mathrm{mg} / \mathrm{kg}$ in urban soils.

The content of other heavy metals: lead, zinc, chromium and cobalt, and PAHs are below the limit values.

Table 4. Average results (in $\mathrm{mg} / \mathrm{kg}$ ) of heavy metals and PAHs in 2010

\begin{tabular}{cccccccccc}
\hline year & Soil type & $\mathbf{P b}$ & $\mathbf{Z n}$ & $\mathbf{C d}$ & $\mathbf{C u}$ & $\mathbf{N i}$ & $\mathbf{C r}$ & $\mathbf{C o}$ & $\mathbf{P A H}$ \\
\hline \hline \multirow{2}{*}{$\mathbf{2 0 1 0}$} & agricultural & 92.70 & 137.5 & 1.89 & 37.68 & 84.58 & 70.52 & 29.68 & 0.19 \\
\cline { 2 - 9 } & urban & 34.08 & 282.7 & 2.60 & 198.3 & 293.5 & 86.03 & 11.40 & 0.34 \\
\hline & Limit values & $<\mathbf{1 5 0}$ & $<\mathbf{3 0 0}$ & $<\mathbf{1}$ & $<\mathbf{1 0 0}$ & $<\mathbf{6 0}$ & $<\mathbf{1 0 0}$ & $<\mathbf{5 0}$ & $<2$ \\
\hline
\end{tabular}

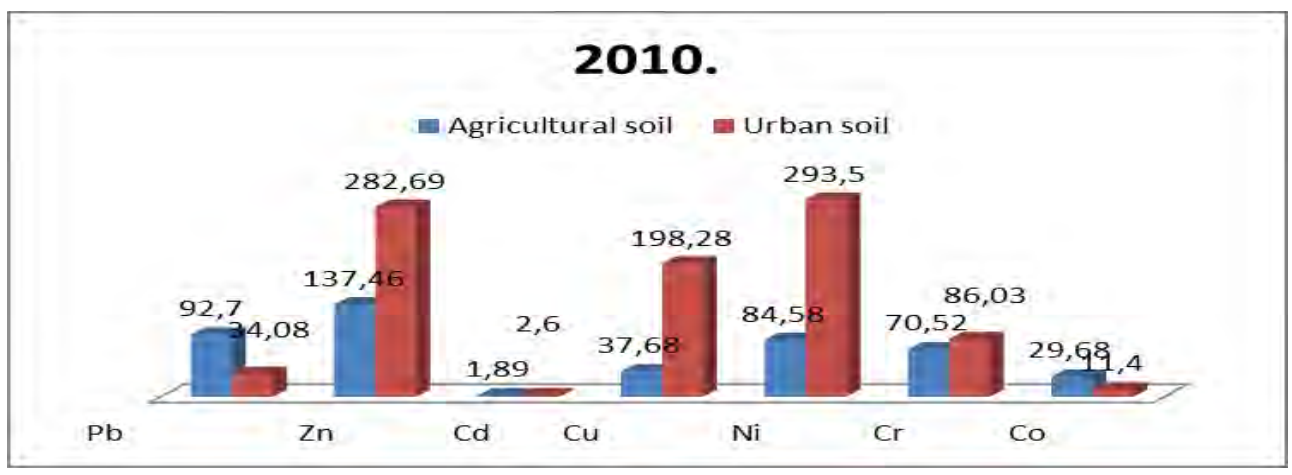

Graph 2. Average results of heavy metals for 2010

- Cadmium content is above the limit value, ranging from $1.89 \mathrm{mg} / \mathrm{kg}$ on agricultural soils, and $2.60 \mathrm{mg} / \mathrm{kg}$ in urban soils.

- Copper content is above the limit value, ranging from $198.28 \mathrm{mg} / \mathrm{kg}$ on agricultural soils, while is below the limit value in urban soils.

- Nickel content is above the limit value, ranging from $84.58 \mathrm{mg} / \mathrm{kg}$ on agricultural soils, and $293.5 \mathrm{mg} / \mathrm{kg}$ in urban soils. PAHs are below the limit values. 
Table 5. Average results (in $\mathrm{mg} / \mathrm{kg}$ ) of heavy metals and PAHs in 2012

\begin{tabular}{cccccccccc}
\hline year & Soil type & $\mathbf{P b}$ & $\mathbf{Z n}$ & $\mathbf{C d}$ & $\mathbf{C u}$ & $\mathbf{N i}$ & $\mathbf{C r}$ & $\mathbf{C o}$ & $\mathbf{P A H}$ \\
\hline \multirow{2}{*}{$\mathbf{2 0 1 2}$} & agricultural & 97.41 & 72.81 & 2.87 & 28.18 & 71.37 & 61.69 & 19.3 & 0.13 \\
\cline { 2 - 9 } & urban & 111.7 & 137.2 & 3.3 & 31.2 & 60.07 & 51.6 & 31.8 & 0.46 \\
\hline & Limit values & $<\mathbf{1 5 0}$ & $<\mathbf{3 0 0}$ & $<\mathbf{1}$ & $<\mathbf{1 0 0}$ & $<\mathbf{6 0}$ & $<\mathbf{1 0 0}$ & $<\mathbf{5 0}$ & $<2$ \\
\hline
\end{tabular}

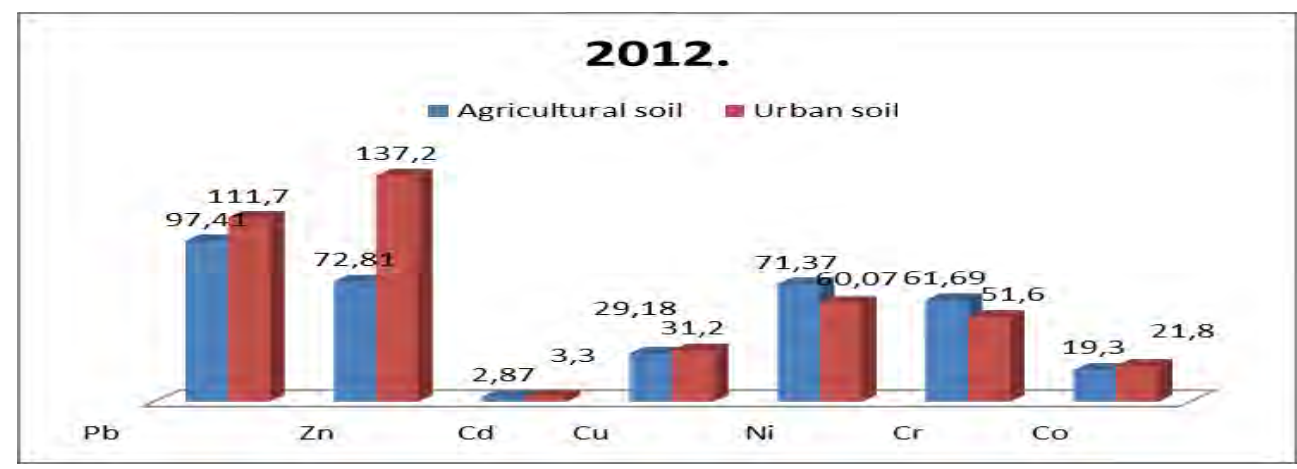

Graph 3. Average results of heavy metals for 2012

- Cadmium content is above the limit value, ranging from $2.87 \mathrm{mg} / \mathrm{kg}$ on agricultural soils, and $3.3 \mathrm{mg} / \mathrm{kg}$ in urban soils.

- Nickel content is above the limit value, ranging from $71.37 \mathrm{mg} / \mathrm{kg}$ on agricultural soils, and $60.07 \mathrm{mg} / \mathrm{kg}$ in urban soils.

The content of other heavy metals: lead, zinc, copper, chromium and cobalt, and PAHs are below the limit values.

Table 6. Average results (in $\mathrm{mg} / \mathrm{kg}$ ) of heavy metals and PAHs in 2013

\begin{tabular}{cccccccccc}
\hline year & Soil type & $\mathbf{P b}$ & $\mathbf{Z n}$ & $\mathbf{C d}$ & $\mathbf{C u}$ & $\mathbf{N i}$ & $\mathbf{C r}$ & $\mathbf{C o}$ & $\mathbf{P A H}$ \\
\hline \hline \multirow{2}{*}{$\mathbf{2 0 1 3}$} & agricultural & 64.61 & 78.1 & 1.77 & 29.17 & 69.55 & 32.29 & 23.73 & 0.12 \\
\cline { 2 - 9 } & urban & 80.57 & 89.05 & 1.54 & 33.05 & 45.07 & 35.8 & 28.16 & 0.45 \\
\hline & Limit values & $<\mathbf{1 5 0}$ & $<\mathbf{3 0 0}$ & $<\mathbf{1}$ & $<\mathbf{1 0 0}$ & $<\mathbf{6 0}$ & $<\mathbf{1 0 0}$ & $<\mathbf{5 0}$ & $<\mathbf{2}$ \\
\hline
\end{tabular}




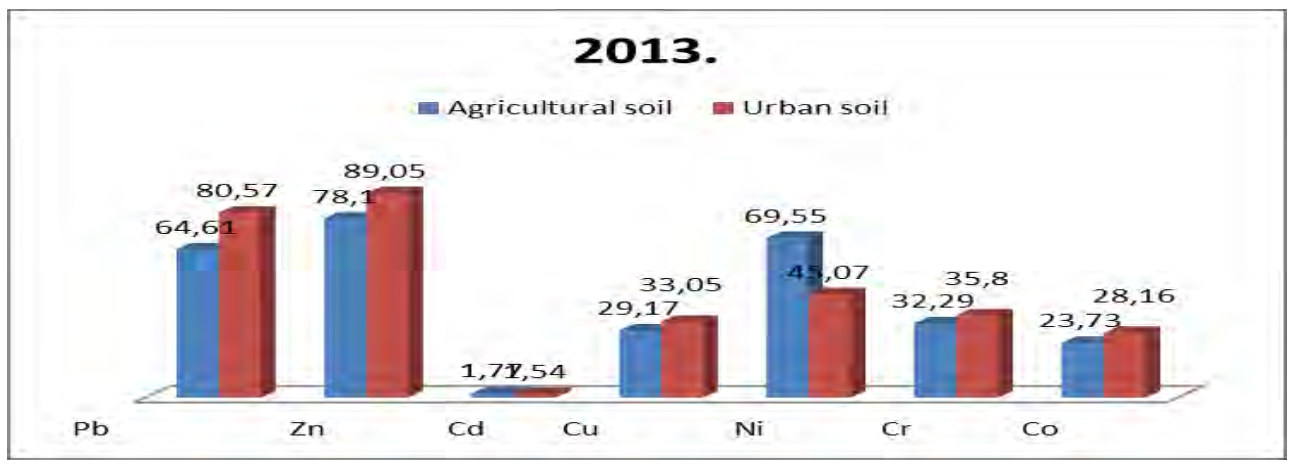

Graph 4. Average results of heavy metals for 2013

- Cadmium content is above the limit value, ranging from $1.77 \mathrm{mg} / \mathrm{kg}$ on agricultural soils, and $1.54 \mathrm{mg} / \mathrm{kg}$ in urban soils.

- Nickel content is above the limit value, ranging from $60.55 \mathrm{mg} / \mathrm{kg}$ on agricultural soils, while $45.07 \mathrm{mg} / \mathrm{kg}$ in urban soils is below the limit value.

The content of other heavy metals: lead, zinc, copper, chromium and cobalt, and PAHs are below the limit values.

Table 7. Average results (in $\mathrm{mg} / \mathrm{kg}$ ) of heavy metals and PAHs in $2014 / 15$

\begin{tabular}{cccccccccc}
\hline year & Soil type & $\mathbf{P b}$ & $\mathbf{Z n}$ & $\mathbf{C d}$ & $\mathbf{C u}$ & $\mathbf{N i}$ & $\mathbf{C r}$ & $\mathbf{C o}$ & $\mathbf{P A H}$ \\
\hline \hline \multirow{2}{*}{$\mathbf{2 0 1 4 -}$} & agricultural & 49.68 & 76.49 & 1.98 & 34.0 & 72.41 & 50.3 & 23.75 & 0.21 \\
\cline { 2 - 10 } & urban & 59.9 & 86.68 & 1.34 & 32.57 & 55.31 & 38.8 & 24.93 & 0.31 \\
\hline \multirow{2}{*}{ Limit values } & $<\mathbf{1 5 0}$ & $<\mathbf{3 0 0}$ & $<\mathbf{1}$ & $\mathbf{1 0 0}$ & $<\mathbf{6 0}$ & $<\mathbf{1 0 0}$ & $<\mathbf{5 0}$ & $<\mathbf{2}$ \\
\hline
\end{tabular}

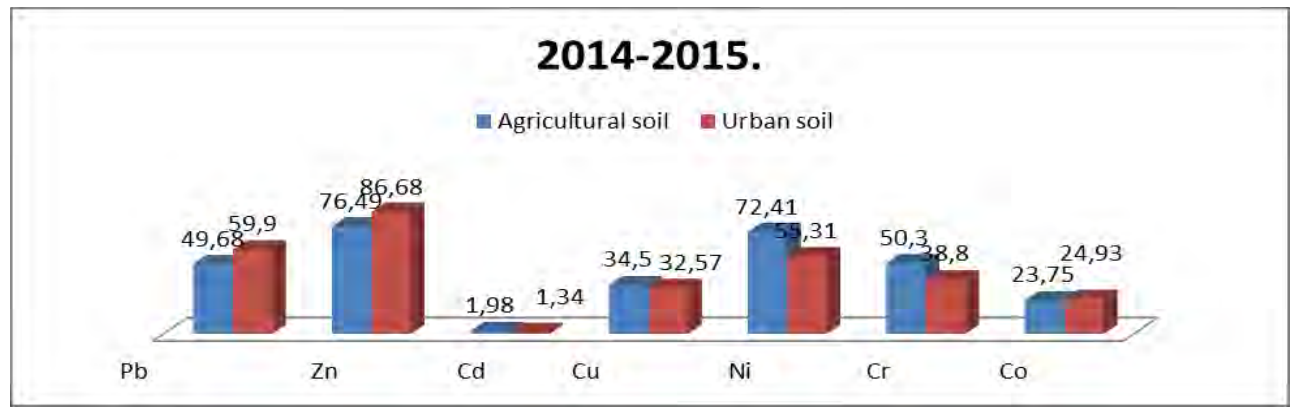

Graph 5. Average results of heavy metals for 2014/15 
- Cadmium content is above the limit value, ranging from $1.98 \mathrm{mg} / \mathrm{kg}$ on agricultural soils, and $1.34 \mathrm{mg} / \mathrm{kg}$ in urban soils.

- Nickel content is above the limit value, ranging from $72.41 \mathrm{mg} / \mathrm{kg}$ on agricultural soils, while $55.31 \mathrm{mg} / \mathrm{kg}$ in urban soils is below the limit value.

The content of other heavy metals: lead, zinc, copper, chromium and cobalt, and PAHs are below the limit values.

\section{DISCUSSION}

Investigations were carried out in the period from 2009 to 2015, on agricultural and urban soils in Canton Sarajevo. Analysis of the soil contamination in the studied period is presented in tables and graphs. Based on the comparison of the obtained average values of heavy metals and PAHs with a limit values, it can be established that the soil of the Canton Sarajevo is slightly exposed to contamination with heavy metals cadmium, nickel and partly with copper. The average concentration of other heavy metals and PAHs do not exceed the permissible limits.

Research conducted in 2009 and 2010 had determined the contamination of urban soil with nickel, copper and cadmium, while in agricultural soils higher contents of cadmium and nickel were found. The data obtained of cadmium content indicate slight contamination in agricultural and urban soils, while data from urban localities indicate intensive contamination with pollutants nickel and copper, whose average values are twice the permissible. The average copper content in urban soils ranged in value of $198.28 \mathrm{mg} / \mathrm{kg}$, and the average nickel content was $293.5 \mathrm{mg} / \mathrm{kg}$.

In the period from 2012 to 2015 the land of Canton Sarajevo was subjected to mild contamination with cadmium and nickel. In agricultural soils the average concentration value was $1.98 \mathrm{mg} / \mathrm{kg}$ for cadmium and $72.41 \mathrm{mg} / \mathrm{kg}$ for nickel.

On investigated localities of the Canton Sarajevo, contamination with other heavy metals was not established. The lead content ranged from 34.08 to $97.41 \mathrm{mg} / \mathrm{kg}$, zinc content from 72.1 to $282.69 \mathrm{mg} / \mathrm{kg}$, chromium content from 32.29 to $86.03 \mathrm{mg} / \mathrm{kg}$ and the content of cobalt ranged from 11.4 to $29.68 \mathrm{mg} / \mathrm{kg}$.

Based on the results of the polycyclic aromatic hydrocarbons content, a slight increase in values in the period from 2010 to 2015 can be observed. The higher content of PAHs was found in urban localities, and lower content on agricultural soils, which seems to be a result of industrialization. The values of the PAHs content in urban soils ranged from 0.314 to $0.461 \mathrm{mg} / \mathrm{kg}$, and for agricultural soils from 0.119 to $0.216 \mathrm{mg} / \mathrm{kg}$. Taking into account that the examined samples are slightly acid to slightly alkaline, this is supported by the fact that in this range of $\mathrm{pH}$ values, heavy metals are less accessible to plants. 


\section{CONCLUSIONS}

Field and laboratory studies were conducted from 2009 to 2015, on agricultural and urban soils in Canton Sarajevo for the presence of heavy metals: lead $(\mathrm{Pb})$, cadmium $(\mathrm{Cd})$, zinc $(\mathrm{Zn})$, nickel $(\mathrm{Ni})$, chromium $(\mathrm{Cr})$, cobalt $(\mathrm{Co})$ and copper $(\mathrm{Cu})$, and the content of PAHs in soil.

In 2009 there was an increased content of cadmium $1.94 \mathrm{mg} / \mathrm{kg}$ in agricultural soils and $2.22 \mathrm{mg} / \mathrm{kg}$ in urban soils, copper $101.51 \mathrm{mg} / \mathrm{kg}$ in agricultural soils and 55.35 $\mathrm{mg} / \mathrm{kg}$ in urban soils and nickel $134.22 \mathrm{mg} / \mathrm{kg}$ in agricultural soils, and $60.04 \mathrm{mg} / \mathrm{kg}$ in urban soils.

In 2010 there was an increased content of cadmium $1.89 \mathrm{mg} / \mathrm{kg}$ in agricultural soils and $2.60 \mathrm{mg} / \mathrm{kg}$ in urban soils, copper $198.28 \mathrm{mg} / \mathrm{kg}$ in urban soils and nickel $84.58 \mathrm{mg} / \mathrm{kg}$ in agricultural soils and $293.50 \mathrm{mg} / \mathrm{kg}$ in urban soils.

In 2012 there was an increased content of cadmium $2.87 \mathrm{mg} / \mathrm{kg}$ in agricultural soils and $3.3 \mathrm{mg} / \mathrm{kg}$ in urban soils and nickel $71.37 \mathrm{mg} / \mathrm{kg}$ in agricultural soils and $60.07 \mathrm{mg} / \mathrm{kg}$ in urban soils.

In 2013 there was an increased content of cadmium $1.77 \mathrm{mg} / \mathrm{kg}$ in agricultural soils and $1.54 \mathrm{mg} / \mathrm{kg}$ in urban soils and nickel $69.55 \mathrm{mg} / \mathrm{kg}$ in agricultural soils and in urban soils the content was below the limit value.

In 2014/15 there was elevated cadmium content of $1.98 \mathrm{mg} / \mathrm{kg}$ in agricultural soils and $1.34 \mathrm{mg} / \mathrm{kg}$ in urban soils and nickel of $72.41 \mathrm{mg} / \mathrm{kg}$ in agricultural soils, while in urban soils the content was below the limit value.

We can observe in 2013, 2014 and 2015 a slight decrease in the content of cadmium and nickel. Elevated concentrations of the se metals in agricultural soils are most likely of the lithological origin; while in urban soils are both lithological and anthropogenic origins.

The concentrations of lead, zinc, nickel, chromium and cobalt are below the limit values. The same can be applied for PAHs compounds. Higher content of PAHs was found in urban localities, while lower was present on agricultural sites as a result of most likely anthropogenic impact.

Since increased concentrations of cadmium, nickel, and copper have a toxic affect on plants, and through them on the animals and humans, it is necessary to conduct more detailed researches of elevated concentrations of cadmium, nickel and copper in Canton Sarajevo. 


\section{REFERENCES}

Čustović H., Žurovec O., Vojniković S., Ljuša M., et al. 2011. A studyof the use value of land of Canton Sarajevo for the necessity of regional planning 2003-2023. University textbook. University in Sarajevo.

Regulation on determining the allowable amounts of harmful and dangerous substances in soils and methods of their examination (Official Gazette of the Federation of B\&H, No. 72/09).

Resulović H.,Čustović H., Čengić I. 2008. Systematic of soil/land. University textbook. University in Sarajevo.

Žurovec O. 2012. Master thesis: The spatial distribution of heavy metals in the soilin the area of Canton Sarajevo due to the soil type and method of use. University textbook. University in Sarajevo. 